\title{
No longer living together: how does Scots cohabitation law work in practice?
}

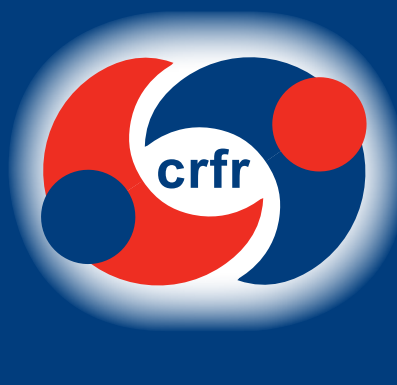

In response to the greater diversity of family life in Scotland, the Family Law (Scotland) Act 2006 gives some recognition to people who live together without marriage or civil partnership and provides limited financial remedies at the end of cohabiting relationships. While these provisions do not give people who live together the same rights as spouses or civil partners, they create a middle way between that protection and none at all. It recognises unmarried cohabitants and gives some protection to those who are economically vulnerable when the relationship ends. This briefing presents research findings from the first study to review how these new provisions work in practice. The research is based on family lawyers' experiences and views of the cohabitation provisions of the 2006 Act.

\section{Key points}

- Solicitors gave the cohabitation provisions a cautious welcome, seeing both benefits and unfulfilled potential. The Act has created financial remedies where none previously existed, recognising the value of financial contributions and the economic sacrifices that often arise from cohabitants' homemaking and childcare activities. Nevertheless, these provisions have both theoretical and operational problems, some intrinsic and others 'early days' effects

- The number of cases family lawyers have dealt with, roughly 1000 , is well below the likely number of cohabiting relationships that end in separation or an intestate death. A much smaller number have made demands on the courts or on legal aid, which indicates that the Act has not imposed an inordinate burden on the Scottish family justice system

- Most cases family lawyers dealt with concerned separation involving couples who were on average older and wealthier, and whose cohabitations were longer than the general population of cohabitants. Very few cases involved short relationships, despite the lack of any minimum duration requirement for cohabitants' relationships to fall within the Act

- Given the estimated scale of use of the legislation and the reported difficulties clients had in understanding the provisions and the advice they were given, there is a need for public legal education, directed towards potential users of the legislation

- The width of the discretion available under both sections 28 and 29 of the Act, the absence of any guidance regarding the objective of financial provision under section 29 and the problems that can be experienced in attempting to prove and quantify economic advantage and disadvantage, leave clients and their advisers uncertain about their position

- The time limits for bringing a claim create further barriers and unnecessarily increases demands on the courts by effectively requiring lawyers to raise and immediately sist (suspend) actions, potentially exacerbating or creating conflict

- Three fifths of cases took under one year to resolve. Longer cases were more likely to involve succession (death of a partner), home owners, or another dispute over child residence or contact, and were more likely to require court involvement

- Lessons from the Scottish experience can inform any reform of the law in England and Wales in relation to cohabitations that end in separation 


\section{Background: the social and legal context}

In Scotland, more people now live together without being married. Also, many more children are born to parents who are not married (about half in 2008) than in the past. In 2006, about one quarter of unmarried adults aged 16 to 59 were cohabiting and, in 2008, there were about 370,000 cohabiting adults in Scotland. Cohabitation is more prevalent amongst younger age groups, with $57 \%$ of all cohabitants aged 34 or less and $81 \%$ aged 44 or less.

While many of the differences between cohabiting and married people are due to their age differences, compared with spouses cohabitants:

- have lower incomes

- receive more income from benefits

- are less likely to be home owners

- are more likely to be tenants

- are less likely to have children, and if they do have children, have smaller family sizes

In response to this change, the Family Law (Scotland) Act 2006 introduced new remedies for cohabitants whose relationships end either by separation or by death. Before the 2006 Act, the financial remedies potentially available to a cohabitant following separation or on death were very limited and often difficult to secure. Many people believed, wrongly, in the 'common law marriage' myth: that after a period of living together, cohabitants had marriage-type rights to financial provision on separation or death.

\section{The study}

The project focused on the experiences and perspectives of family lawyers on the use of the cohabitation provisions of the Act during its first three years of operation. It also included a review of all of the reported cases involving those provisions.

The study included:

- a survey of 97 family lawyers, mainly members of the Family Law Association, using an online questionnaire

- semi-structured in-depth telephone interviews with 19 family lawyers whose questionnaire responses raised issues to be pursued in greater depth

The survey asked respondents about themselves, their caseloads, their last completed cohabitation case, followed by questions about their wider views of these provisions. The in-depth interviews had some personalised elements and were designed to seek elaboration of issues they raised, such as reflections on which aspects of the provisions worked well or did not. Each interviewee was asked to comment on a vignette involving either a separation or death, depending upon which of these was their last case. The vignettes allowed interviewees to reflect on a common set of circumstances.

\section{Cohabitation provisions of the Family Law (Scotland) Act 2006 summarised}

Section 25 defines a cohabitant as either member of a couple who live or lived together as if they were husband and wife (if of the opposite sex) or as if they were civil partners (if of the same sex). In determining whether two people are cohabitants, the court must consider the nature and duration of their relationship and any financial arrangements between them during that period. No minimum period of cohabitation is stipulated in order to use the Act.

Section 26 provides for the division of household goods acquired during cohabitation (but not before it), except for money, securities, cars and pets. Except for goods acquired as gifts or by inheritance, it presumes joint ownership unless there is proof that the parties contributed to their acquisition in unequal shares.

Section 27 provides that assets (other than the family home) acquired from savings made from a housekeeping allowance paid by one cohabitant to the other will be owned in equal shares, in the absence of some other agreement.

Section 28 gives the courts power to order a capital sum following separation, either to assist with the ongoing economic burden of caring for the cohabitants' children or to correct any imbalance in economic advantage and disadvantage between the parties. Any such claim must be brought within one year of the separation.

Section 29 applies if a cohabitant dies intestate (that is, without a will). A surviving cohabitant may bring a claim within six months of the death for a share of the estate. The court has a wide discretion to order a capital sum or the transfer of property from that estate.

It is possible under the general law for cohabitants to opt out of these provisions by making agreements at any time that waive their rights to bring claims under the Act. 


\section{Vignettes}

There were two vignettes, one with a succession problem, the other on separation, allowing a comparison of how different solicitors approached a common set of facts and what difference the 2006 Act made in those particular circumstances.

Succession. Eleanor's partner David died 3 months earlier in a car accident, and she has just discovered he left no will, and had not actually divorced his wife. They had lived together for 12 years and at the time of David's death were living in a large house that David owned and financed with one child from his marriage, aged 17 , and their two children, aged 8 and 6 . David, a hospital doctor, was the main earner, although Eleanor worked part time.

Separation. Janet and Kenneth, who have separated, have lived together for about seven years and have twins aged 4. They live in a house that Kenneth owns, but to which Janet has contributed substantially. Janet supported the couple when Kenneth had to retrain after being made redundant but she gave up her job to look after their children and Kenneth has been the sole earner.

\section{The findings}

\section{Lawyers think provisions are better, but not perfect}

Some solicitors felt the provisions went too far establishing rights for people who live together.

I'm personally very much against cohabitants having any rights at all, quite frankly. I think if they want rights they should get married.

However, the Act was seen by a number of solicitors as being better than what had previously existed.

It's good that there has been some kind of recognition of how our social structure has changed.

At the most basic level, the provisions were welcomed because they acknowledged 'the fact that cohabitants have recognised rights'. The provisions offered a foundation for negotiation between the parties since they provided 'a massive bargaining tool'.

[The Act] does give people a bit, a bit of a lifeline if they're the weaker party certainly.

While most solicitors broadly welcomed having some financial remedies available for cohabitants whose relationships end, they agreed on the whole with the legislation's approach that these should be more limited than those available at the end of a marriage or civil partnership.

I welcome the fact that it didn't try and go as far as marriage did.

It's right that those that have chosen not to get married should not have the same rights as those who are married ... and ... it is absolutely correct, from a social policy point of view, that there is a difference in the financial positions of those that are married and those that are not.

However, despite general support, lawyers felt the Act could be better.

I suppose I welcome the fact that there is recognition of an entitlement on the part of cohabitees ... It could have been done better, as anything could always be done better.

After lengthy cohabitations, the Act was seen as having the potential 'to correct an unfairness on separation'. However, this interviewee, who saw such potential, qualified the comment: 'I think it's very, very difficult to use in practice'.

Some solicitors found that the limited range of remedies, in particular, the lack of powers to transfer property or (apparently) to order periodical allowances for child-care, was problematic. Whilst meeting the policy objective of limiting the scope of rights available to cohabitants, lawyers and the courts are left with only the blunt instrument of capital awards to achieve a clean financial break and an equitable settlement.

\section{Nature of cases}

Most of the last cases reported in the questionnaires involved separation (79\%), rather than the death of a partner. About three-quarters (73\%) involved cohabitations of 6 years or more, considerably longer than the average duration of cohabitations in the general population. A large minority of cases involved dependent children (44\%). The great majority of clients and the other party were in paid employment, legally represented, homeowners, and aged over 35. A minority of cases were supported by legal aid in whole or in part.

Just over one-third of these cases were settled without court involvement, a slightly higher number (42\%) were resolved with court involvement. This high figure is likely to be largely due to having raised, and then immediately stopped the court action, in many cases because of time limits imposed by the legislation. 
Three-fifths of cases took a year or less between first client contact and close of the case. The cases that took longer to resolve were more likely to involve:

- the death of a partner

- clients who were home owners

- legal aid

- another dispute over residence or contact

- court involvement with resolution

\section{Limited use of the provisions}

Based on replies to a question on the size of their relevant caseloads since 2006 , we can very roughly estimate that 1000 cohabitation cases have come to the attention of family lawyers since the Act came into force. The numbers involving substantial attention of the courts is far less. This number is well below the likely number of cohabiting relationships that end in separation or death and the provisions therefore appear not to have imposed an inordinate burden on the Scottish family justice system.

The apparently limited use of the provisions may be due to several reasons, such as:

- couples having no property to redistribute

- the limited nature of the provisions

- ignorance about the provisions or their existence

- redistribution being agreed by other means, e.g. joint ownership or deceased's will

- redistribution being agreed privately by the couple, without solicitors, possibly with each partner leaving with their own property and assets after a short cohabitation

\section{Clients' limited knowledge of provisions}

Family lawyers reported that many clients had difficulty in understanding the information they were given and, to a slightly lesser extent, the advice provided. Many solicitors were concerned that the level of 'widespread ignorance' of the provisions was profound, because 'if the public don't know about it, they'll not claim'. Another solicitor commented:

The big problem in [the] cohabitation statute - ... public education.

\section{Problems quantifying economic advantage and disadvantage}

The interpretation, proof and quantification of economic advantage and disadvantage and the width of the court's discretion were the top two problems with the cohabitation provisions according to the solicitors involved in the study.

Many commented on the lack of guidance and the practical difficulties in establishing a claim based on section 28 that requires quantifying the economic advantage and disadvantage of each cohabitant. That, combined with the wide discretion available to the courts, made it difficult for them to advise their clients. Several interrelated issues made quantifying the balance of economic advantage and disadvantage difficult to pursue to a successful conclusion. They include:

- explaining the concept to clients

- relating it to their situation

- agreeing what constitutes an advantage and a disadvantage

- proving the claim

These problems could potentially improve to some extent as solicitors gain further experience and as case law develops.

\section{Lawyers' Reflections: separation vignette}

The separation vignette showed the difficulty family lawyers face in using section 28 . This is particularly true in low-value cases where there was little money about which to argue and there was a need to manage clients' expectations.

Addressing the outcome as it would have been before 2006, one solicitor said:

I would have been hanging my head when the woman left and thinking, 'Oh dear, what can we possibly do for this woman?' Very, very little to be honest.

It was generally thought that Janet was in a much better position as a result of the 2006 Act and there was some basis upon which to negotiate a settlement. However, some interviewees considered her situation now to be only a bit better:

It's very useful that we've got an Act, but it's not a major player here.

Lawyers were practically oriented, mindful of Janet's welfare benefit entitlement, legal aid issues, and the affordability for both parties of various housing options and the fate of the home. Negotiation was clearly preferred to litigation as a more certain and cost-effective path and better for the children:

People are settling because they know what they're getting, rather than risking going to court.

The focus for most was on achieving a child-centred solution that included child support, perhaps a sum towards childcare costs, and the father's continuing involvement in the children's lives, but recognising that it would probably be necessary for the family home to be sold, and for Janet and the children to move to something more modest, quite possibly rented. 
In-depth interviews with family lawyers indicated that while there remains a level of uncertainty about its operation, many thought that it would become more effective over time and with experience and more case law.

Some solicitors saw the width of the court's discretion in a mixed light. For example, the section 28 provision of 'a general capital sum payment ... [was] very woolly' but had the advantage of affording 'a lot of flexibility to the court'. Also, in separation cases involving children, some solicitors thought the provisions were helpful for making claims 'for a share of future child care costs'. [see Lawyers' Reflections: separation vignette]

Solicitors also noted that the guidance as to how to quantify a claim under section 29 could be clearer. The section 27 'housekeeping allowance' was seen as 'archaic'.

\section{Lawyers' Reflections: succession vignette}

In the succession vignette, it was widely felt that the impending time bar for a claim under s 29 would almost inevitably mean having to raise and then sist an action immediately, since it was unlikely that all necessary information could be gathered (especially from the pension provider) or negotiation undertaken within the three months remaining until the six month cut off point - but the aim, having secured Eleanor's position with a raise and sist, would be to negotiate a settlement.

This vignette also illustrated the potential conflict of interest between a surviving cohabitant and her children, who would also be entitled to inherit part of the estate, and the difficulty in having the surviving cohabitant act as executor for the estate.

\section{Six month time limit is too short}

While most solicitors appreciated that time limits for claiming were needed, there was widespread unease about the shortness of the time limits in both separation and succession cases.

The time limits had the unintended consequence of causing more litigation than was likely with a longer period. Of the two, the time limits for succession cases caused most concern. Grieving may take longer than six months, a badly injured surviving cohabitant may miss the deadline, and it is impossible to extend the six month limit.

Six months is a very short period of time to instigate action and it has meant ... you've had to ... put an action into court and then just immediately sist [stop] it, whilst you consider to negotiate. I think it's unhelpful, sometimes with a death it's very sensitive and you are talking about ... hav[ing] to raise a court action....
The time limit in separation cases can also lead to cases being raised then stopped to allow negotiation to continue whilst preserving the possibility of going to court should negotiations fail. A lengthier time limit would give clients more time to attempt negotiation without having to worry about time running out and so without appearing to raise the stakes by initiating a court action. Several respondents also mentioned that establishing the date of separation was problematic. [see Lawyers' Reflections: succession vignette]

\section{Implications for Scotland}

Have the cohabitation provisions of the 2006 Act met their policy objectives? Are there unintended consequences, and if so, do these impede the realisation of the particular policy objectives or other policy objectives?

The Act has undoubtedly achieved a lot for Scottish cohabitants and their children. It has created financial remedies where none previously existed, recognising the value of financial contributions and the economic sacrifices that often arise from cohabitants' homemaking and childcare activities. The Act reflects opinion in Scotland that cohabitation should not be treated in the same way as marriage, but can help to prevent injustices or hardships that may arise, especially if children are involved.

Our findings suggest that, less than four years in, the Act's main strengths lie principally at a normative level, and law and practice under the 2006 Act are still some way from achieving the stated objectives. Nevertheless, the Act provides practitioners and their clients with a potential claim with which to enter into negotiations for settlement when cohabitation ends, whether by death or separation.

The absence of a minimum duration requirement for eligibility to bring a claim either on separation or death has not resulted in a flood of claims following short relationships; very few of respondents' last cases involved relationships of under two years. However, this research has identified various operational problems that prevent many from realising the benefits which it was intended to confer. These difficulties can be broadly placed in two categories, with some having elements of both:

- Intrinsic problems: factors such as the time limits and limited range of remedies which arise from the scheme as currently enacted which can only be ameliorated by reform of the primary legislation

- Early days effects: problems being felt now which may ameliorate over time as the Act beds down, practitioners become more familiar with its operation, and the apparently wide discretion created by the Act is reined in by clearer judicial guidance, in particular on the operation of the economic advantage and disadvantage principle and the s 29 discretion 


\section{Implications for England and Wales}

There have been remedies for cohabitants on death in England and Wales since 1995. But what, if anything, can recent Scottish experience suggest for any future reform in England and Wales relating to separation?

In light of widely acknowledged criticisms of the current law, various recommendations have been made for statutory financial remedies between cohabitants on separation, recently by the Law Commission and in two Private Members' Bills.

As with any policy learning, caution is needed in drawing conclusions for England and Wales from the Scottish experience owing to the differences between the 2006 Act and the schemes advocated for England and Wales, together with the different legal frameworks in which they would operate. However, we think these findings offer some messages that may assist the formulation and execution of policy south of the border:

- A time limit of one year from separation to bring a claim gives rise to unintended and undesirable consequences, making applicants feel obliged to start (but then immediately suspend) a court action to avoid time running out while attempts are made to use alternative dispute resolution procedures; this burdens court administration and other parts of the family justice system, including legal aid
- The limited range of orders available under the 2006 Act, whilst consistent with the intended limited scope of the legislation, can (in some circumstances) result in unfairness to both parties

-Whatever basis for relief is chosen for a new scheme, it brings its own pros and cons. The operation of any principle, such as economic advantage and disadvantage, which depends on individual circumstances and their economic effect necessarily demands a particular type of evidence which may not always be easy to adduce. But if similar principles were adopted as part of any reform in England and Wales, clearer and more comprehensive statutory drafting would go some way to avoid the uncertainty currently being experienced in operating the 2006 Act's principles

- Despite the lack of minimum duration requirement in the 2006 Act, there has been no flood of cases in the first three or so years of the Act's operation. Imposing a minimum duration of two years would have made hardly any difference to the number of potential cases seen by solicitors. The Scottish evidence to date suggests that the introduction of broadly similar provisions in England and Wales would not place significant additional demands on court and legal aid resources

\section{Authors \\ This briefing was written by Fran Wasoff, Jo Miles and Enid Mordaunt and edited by Jennifer Flueckiger.}

The study, funded by the Nuffield Foundation, was carried out by Fran Wasoff, Centre for Research on Families and Relationships, The University of Edinburgh, Jo Miles, Trinity College, University of Cambridge and Enid Mordaunt, Centre for Research on Families and Relationships, The University of Edinburgh.

The full report can be read and downloaded:

http://www crfr.ac.uk/researchprojects/rp_cohabitation.html 

Centre for Research on Families and Relationships The University of Edinburgh, 23 Buccleuch Place, Edinburgh EH8 9LN
Tel: 01316511832

Fax: 01316511833

E-mail: crfr@ed.ac.uk 